\title{
PENGARUH KETERSEDIAAN PRASARANA DAN SARANA TERHADAP NILAI LAHAN PEMUKIMAN DI MAKASSAR
}

\author{
Noviar Nurdin Kasim ${ }^{1}$, Pratiwi Juniar A. G ${ }^{2}$ \\ ${ }^{1}$ Jurusan Arsitektur, Universitas Fajar, ${ }^{2}$ Jurusan Arsitektur, Universitas Muslim Indonesia
}

\begin{abstract}
Abstrak
Perkembangan penduduk yang semakin hari semakin padat, maka kebutuhan akan perumahan juga akan semakin bertambah. Hal ini terlihat dari semakin berkembangnya usaha-usaha dalam bidang perumahan, baik yang diselenggarakan oleh pihak pemerintah (Perum Perumnas) maupun yang diselenggarakan oleh pihak swasta. Menurut Undang_undang Tata Ruang dimana dinyatakan bahwa setiap pembangunan perumahan harus ditunjang oleh kelengkapan prasarana dan sarana lingkungan. Namun ketentuan yang dipersyaratkan ini kadang tidak semua terpenuhi, terlihat masih banyak perumahan yang belum memiliki prasarana dan sarana lingkungan yang memadai sesuai dengan ketentuan yang dipersyaratkan. Penelitian ini bertujuan untuk mengetahui apakah faktor ketersediaan prasarana dan sarana berpengaruh signifikan terhadap nilai lahan pemukiman di kota Makassar dan untuk mengukur tingkat signifikansi pengaruh ketersediaan prasarana dan sarana terhadap nilai lahan pemukiman di kota Makassar. Metode penelitian yang digunakan adalah penelitian kuantitatif eksplanatori yaitu suatu jenis penelitian yang menjelaskan tentang pengaruh variabel independen terhadap variabel dependen dengan uji hipotesis. Temuan-temuan yang dihasilkan adalah prasarana dan sarana memberikan kontribusi pengaruh terhadap nilai lahan perumahan sebesar $65 \%$ dan $46,5 \%$. Dengan tersedianya prasarana dan sarana perumahan. maka nilai lahan yang dimiliki oleh suatu perumahan tinggi. Anggota dari variabel bebas prasarana yang paling dominan berpengaruh terhadap nilai lahan adalah prasarana jalan dan anggota dari variabel bebas sarana yang paling dominan berpengaruh terhadap nilai lahan adalah sarana pendidikan.
\end{abstract}

Kata kunci: Ketersediaan prasarana, ketersediaan sarana, nilai lahan, pemukiman

\begin{abstract}
The development of the population that is increasingly congested, so the need for housing will also increase. It looks from the development efforts to increasing the number of housing development, both held by the government (Perum Perumnas) and by the private sector. According to UU Tata Ruang where it is stated that any housing development should be supported by the availability of infrastructure and facilities. But these provisions required and sometimes not at all met, there are still a lot of housing that do not have infrastructure and facilities in accordance with the provisions required. This research aims to determine whether the availability of infrastructure and facilities for a significant effect on the value of residential land in Makassar and to measure the level of significance of the effect of the availability of infrastructure and facilities to the value of residential land in Makassar. The methods of this research used is quantitative research explanatory which is a type of research that describes the influence of the independent variable on the dependent variable to test the hypothesis. The resulting findings that infrastructure and facilities contributing to influence on the value of land for housing at $65 \%$ and $46.5 \%$. With the availability of infrastructure and housing facilities. then the value of land owned by a housing becomes higher. Members of the independent variable for infrastructure where being the most dominant to gives an effect on the value of land is the road infrastructure and a member of the independent variables for facilities where being the most dominant to gives an effect on the value of land is an education facilities.
\end{abstract}

Keywords : availability of infrastructure, availability offacilities, settlement, the value of land

\section{PENDAHULUAN}

Seiring dengan perkembangan penduduk yang semakin hari semakin padat, maka kebutuhan akan perumahan juga akan semakin bertambah. Hal ini terlihat dari semakin berkembangnya usaha-usaha dalam bidang perumahan, baik yang diselenggarakan oleh pihak pemerintah (Perum Perumnas) maupun yang diselenggarakan oleh pihak swasta. Menurut Undang_undang Tata Ruang dimana dinyatakan bahwa setiap pembangunan perumahan harus ditunjang oleh kelengkapan prasarana dan sarana lingkungan. Namun ketentuan yang dipersyaratkan ini kadang tidak semua terpenuhi, terlihat masih banyak perumahan yang belum memiliki prasarana dan sarana lingkungan yang memadai sesuai dengan ketentuan yang dipersyaratkan.

Sadar atau tidak para investor harus ingat bahwa kelengkapan/ketersediaan prasarana dan sarana lingkungan dapat menjadi daya tarik tersendiri terhadap perumahan yang dikelolanya, sehingga pemukim atau calon penghuni perumahan akan merasa nyaman untuk tinggal karena apa yang menjadi kebutuhan hidup sehari-hari 
mereka/keluarga dapat diperoleh dengan mudah dan cepat sehingga dengan demikian dapat lebih ekonomis baik dari segi waktu, tenaga dan dana. Dahulu orang akan memilih tempat tinggal yang mempunyai lokasi/letak yang strategis dalam arti terletak dipusat kota, jangkauan kemana-mana mudah, namun sekarang seiring dengan perkembangan kota, sebagai akibat perkembangan jumlah penduduk perkotaan maka dimanapun letak/lokasi perumahan tersebut tidak masalah yang penting pemukiman tersebut dilengkapi prasarana dan sarana yang cukup sesuai dengan ketentuan Undang-Undang Tata Ruang. Banyak kebijakankebijakan yang memberikan pengaruh penting terhadap nilai lahan seperti dengan ketersediaan sarana dan prasarana perumahan yang sesuai dengan kebutuhan kota dan dinamika kelangsungan hidup masyarakat.

Faktor-faktor yang mempengaruhi nilai lahan dalam suatu kota sangat bergantung kepada kelengkapan sarana dan prasarana yang mendukung, sehingga nilai lahan tersebut meningkat. Ini dapat dilihat dari perumahan-perumahan yang dibangun baik yang ada didaerah pusat kota maupun yang ada di daerah pinggiran kota, nilai lahannya tinggi karena memiliki kelengkapan prasarana dan sarana. Oleh karena itu, dapat dikatakan bahwa faktor-faktor yang mempengaruhi nilai lahan sangat ditentukan oleh variabel-variabel prasarana dan sarana. Adapun prasarana yang mempengaruhi nilai lahan yaitu ketersediaan jalan, drainase, air bersih, penerangan listrik, jaringan telepon. Sedangkan sarana yang mempengaruhi nilai lahan adalah sarana pendidikan, kesehatan, peribadatan dan olahraga/rekreasi serta sarana perbelanjaan (pasar). Kebanyakan dalam suatu perumahan, ditemukan adanya fenomena masalah bahwa ketersediaan prasarana dan sarana belum mencukupi baik ditinjau dari segi ketersediaannya maupun dari segi kapasitasnya. Oleh karena itu, sebagai bahan pertimbangan bagi investor/pengelola pemukiman untuk mendapatkan nilai jual tanah/ rumah yang tinggi maka faktor ketersediaan prasarana dan sarana harus menjadi bahan pertimbangan/perhatian.

Berdasarkan masalah diatas, maka hipotesis penelitian ini adalah ketersediaan prasarana dan sarana baik secara parsial maupun simultan berpengaruh signifikan terhadap nilai lahan pemukiman di Kota Makassar.

\section{ISI PENELITIAN}

\subsection{Metode Penelitian}

a. Pendekatan Penelitian,

Pendekatan yang digunakan adalah pendekatan kuantitatif, yaitu pendekatan yang memungkinkan dilakukan pencatatan dan analisis data hasil penelitian secara eksak dan analisis datanya menggunakan perhitungan statistik. Teknik pengumpulan data yang digunakan dalam penelitian ini adalah angket terbuka untuk data nilai lahan perumahan dan angket tertutup untuk data prasarana dan sarana.

c. Tempat dan Waktu Penelitian

Tempat penelitian ini dilaksanakan pada tiga kecamatan di Makassar yaitu pada Kecamatan Biringkanaya, Tamalanrea, dan Panakukang, yaitu pada perumahan yang dianggap dapat mewakili sebagai obyek penelitian dengan pertimbangan bahwa tempat populasi berada pada daerah pusat dan pengembangan kota Makassar, yang cukup memenuhi persyaratan untuk diambil sebagai lokasi penelitian karena:

1. Kecamatan Panakukang, sesuai dengan Rencana Umum Tata Ruang Kota dengan fungsi utama; sebagai pusat perdagangan dan jasa sosial serta ungsi penunjang; pemukiman, pendidikan, perkantoran, terminal angkot dan ruang terbuka hijau.

2. Kecamatan Tamalanrea, sesuai dengan RUTRK dengan: fungsi utama; pendidikan tinggi dan pemukiman serta fungsi penunjang; jasa sosial/umum, pemukiman, taman/ hutan kota.

3. Kecamatan Biringkanaya, sesuai dengan RUTRK dengan fungsi utama; industri dan pemukiman serta fungsi penunjang; terminal angkutan darat, ruang terbuka hijau dan pekuburan.

Adapun letak/ lokasi dari ketiga kecamatan terpilih sebagai lokasi penelitian dapat dilihat pada gambar berikut :

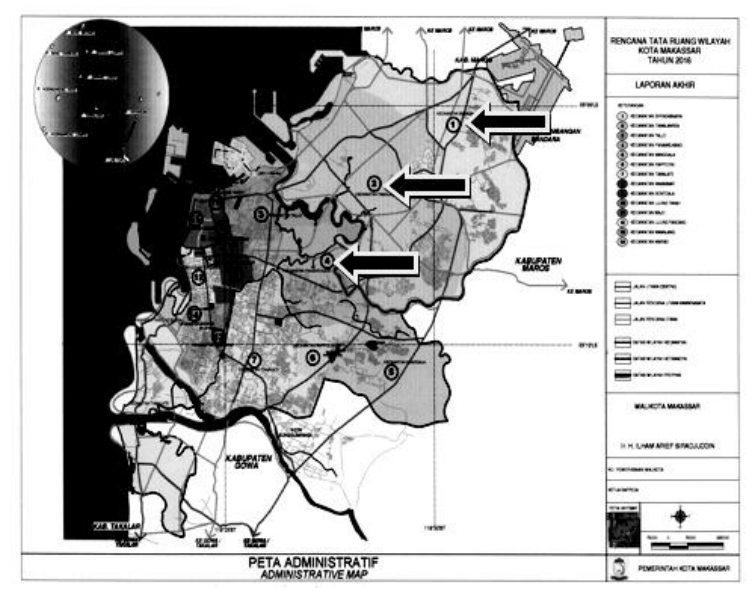

Gambar 1. Lokasi Penelitian

d. Teknik Analisis Data

Teknik analisis data menggunakan pendekatan statistik infrensial parametrik, dengan uji normalitas distribusi frekuensi dan uji linearitas regresi. Analisis statistik infrensial parametrik yang digunakan adalah regresi linear berganda.

\subsection{Hasil Analisis}

\section{a. Nilai Lahan}

Nilai lahan adalah nilai jual lahan perumahan secara rata-rata sesuai dengan harga jual dan kemampuan membeli tanah dengan satuan rupiah/ $\mathrm{M}^{2}$ tanah perumahan. Nilai lahan ditentukan oleh luas lahan, letak lahan, harga lahan kelas lahan, dan nilai jaminan lahan. Lebih jelasnya dapat dilihat 
melalui tanggapan dari responden mengenai nilai lahan pada tabel 1 dibawah ini.

Tabel 1. Distribusi Frekuensi dan Persentase Responden mengenai Nilai Lahan

\begin{tabular}{|c|c|c|c|}
\hline No & Kategori & $\begin{array}{c}\text { Frekuensi } \\
\text { (orang) }\end{array}$ & $\begin{array}{c}\text { Prosentase } \\
(\mathbf{\%})\end{array}$ \\
\hline 1 & $\begin{array}{c}\text { Sangat } \\
\text { tinggi }\end{array}$ & 8 & 14,8 \\
\hline 2 & Tinggi & 9 & 16,7 \\
\hline 3 & Sedang & 15 & 27,8 \\
\hline 4 & Rendah & 9 & 16,7 \\
\hline 5 & $\begin{array}{c}\text { Sangat } \\
\text { rendah }\end{array}$ & 13 & 24,1 \\
\hline & Total & 54 & 100 \\
\hline
\end{tabular}

Sumber : Data setelah diolah, 2010

Tabel 1 diatas memperlihatkan terdapat 15 responden menyatakan nilai lahan perumahan yang tersedia sedang dengan tingkat persentase $27,8 \%$ adalah yang tertinggi, dan terdapat 8 responden yang menyatakan nilai lahan yang tersedia sangat tinggi dengan tingkat persentase $14,8 \%$ adalah yang terendah, jelasnya dapat dilihat pada gambar 8 berikut ini:

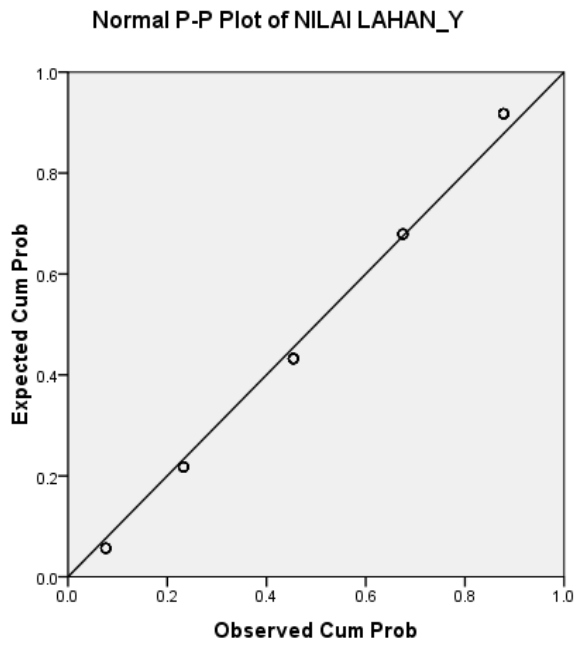

Gambar 2. Grafik Nilai Lahan

Untuk variabel terikat nilaiu lahan pada grafik normal P-P plot nilai lahan terlihat bahwa nilai harapan dari penggunaan lahan menurut tingkat probabilitas yang berpengaruh meningkat diatas 0,6 dan di bawah 0,8 sebagai nilai terendah, dan nilai tertinggi berada dibawah 1,0 dan diatas 0,8 .

Gambar grafik di atas menunjukan bahwa nilai lahan perumahan di tiga kecamatan (Panakukang, Tamalanrea, dan Biringkanaya) nilai kegunaannya tinggi. Jadi dengan tersedianya prasarana dan sarana pada perumahan tersebut, akan memberikan peningkatan terhadap nilai lahan Dimana nilai lahan yang dimaksud ditentukan oleh letak/lokasi aksesibilitas, kelas tanah yang digunakan, dan adanya nilai jaminan atas tanah.
Batasan mengenai pengertian nilai lahan dalan tinjauan pustaka adalah nilai yang dihitung dalam harga rata-rata tanah yang dimanfaatkan atau digunakan, dimana bila dijual mempunyai nilai beli yang biasanya dinyatakan dalam unit satuan rupiah. nAdapun nilai lahan sangat ditentukan oleh: (1) lokasi/letak, (2) Kelas lahan, (3) luas lahan, (4) harga lahan, dan (5) nilai jaminan lahan.

\section{b. Prasarana}

Prasarana adalah kondisi tanah dan lingkungannya serta struktur pendataan dan pengaturan yang menyebabkan nilai lahan perumahan bernilai ekonomis. Prasarana yang dimaksod adalah prasarana perumahan yang terdiri dari jaringan jalan, drainase, jaringan air bersih, jaringan listrik dan jaringan telepon. Lebih jelasnya dapat dilihat tanggapan dari responden mengenai prasarana pada tabel 2 .

Tabel 2. Distribusi Frekuensi dan Persentase Responden mengenai Prasarana

\begin{tabular}{|c|c|c|c|}
\hline No & Kategori & $\begin{array}{c}\text { Frekuensi } \\
\text { (orang) }\end{array}$ & $\begin{array}{c}\text { Persentase } \\
(\mathbf{\%})\end{array}$ \\
\hline 1 & Sangat tersedia & 7 & 13,0 \\
\hline 2 & Tersedia & 7 & 13,0 \\
\hline 3 & Agak tersedia & 15 & 27,8 \\
\hline 4 & Kurang tersedia & 12 & 22,2 \\
\hline 5 & Tidak tersedia & 13 & 24,1 \\
\hline & Total & 54 & 100 \\
\hline
\end{tabular}

Sumber : Data setelah diolah, 2010

Tabel 2 memperlihatkan ada 7 responden menyatakan prasarana perumahan sangat tersedia dan tersedia dengan tingkat persentase 13,0\% adalah yang terendah, dan terdapat 15 responden menyatakan prasarana perumahan agak tersedia dengan tingkat persentase $27,8 \%$ adalah yang tertinggi. Jelasnya dapat dilihat pada gambar 3 .

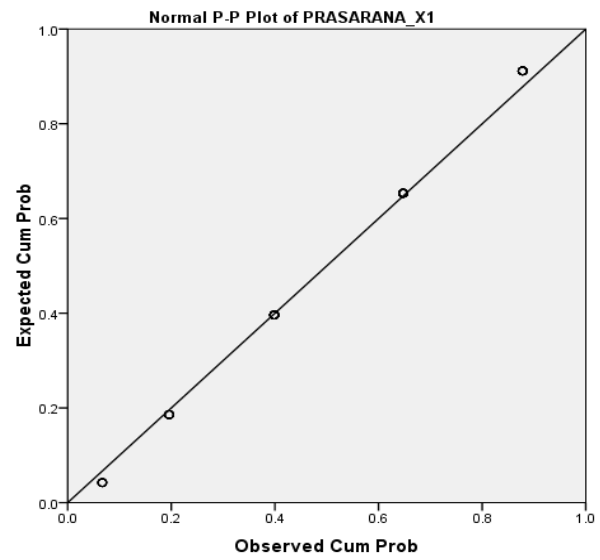

Gambar 3. Grafik Prasarana

Menurut untuk variabel bebas prasarana pada grafik normal P-P plot prasarana (X1) yang berpengaruh terlihat pada nilai harapan dari penggunaan lahan menurut tingkat probabilitas yang berpengaruh meningkat diatas 0,6 dan dibawah 0,8 
yang terendah, dan yang tertinggi dibawah 1,0 dan di atas 0,8 .

Gambar grafik garis untuk prasarana di atas menunjukan bahwa ketersediaan prasarana pada perumahan di kecamatan Panakukang, Tamalanrea dan Biringkanaya agak tersedia maka perlu lebih di tingkatkan sehingga memberikan pengaruh lebih terhadap nilai lahan. Variabel prasarana yang dimaksud adalah jaringan jalan, drainase, air bersih, listrik dan telepon.

Jadi pembangunan prasarana permahan di perkotaan, baik yang dikelola pemerintah maupun oleh pihak swasta ataupun masyarakat cenderung menginginkan adanya kebutuhan akan kelengkapan prasaran lingkungan. Ini sesuai dengan apa yang dikemukakan oleh Sterman (2000) dalam tinjauan pustaka, mengenai pentingnya pemahaman prasarana di dalam melihat obyek pemukiman, yakni keputusan prasarana mempunyai indicator untuk sebuah pembangunan perumahan yang terdiri dari infrastruktur yang trsedia seperti jaringan jalan, drainase, air bersih, listrik dan telepon.

Ini juga didasarkan pada keputusan Menteri PU no.20/KPTS/1986, tentang Pedoman Teknis Pembangunan Perumahan Sederhana, menjelaskan tetang prasarana yang meliputi jalan, drainase, air bersih, listrik dan telepon layak tersedia pada setiap pembangunan perumahan yang siap huni guna memberikan kenyamanan bagi penghuni.

\section{c. Sarana}

Sarana adalah fasilitas yang mendukung aksesibilitas tanah yang bernilai ekonomis, sehingga tanah tersebut bernilai jual yang tinggi. Sarana yang dimaksud yaitu fasilitas perumahan berupa sarana pendidikan, kesehatan, peribadatan, olahraga/ rekreasi dan pasar, lebih jelasnya dapat dilihat tanggapan dari responden mengenai sarana pada tabel 3 dibawah ini.

Tabel 3 Distribusi Frekuensi dan Persentase Responden mengenai Sarana.

\begin{tabular}{|c|c|c|c|}
\hline No & Kategori & $\begin{array}{c}\text { Frekuensi } \\
\text { (orang) }\end{array}$ & $\begin{array}{c}\text { Persentase } \\
(\boldsymbol{\%})\end{array}$ \\
\hline 1 & Sangat tersedia & 7 & 13,0 \\
\hline 2 & Tersedia & 8 & 14,8 \\
\hline 3 & Agak Tersedia & 14 & 25,9 \\
\hline 4 & $\begin{array}{c}\text { Kurang } \\
\text { Tersedia }\end{array}$ & 12 & 22,2 \\
\hline 5 & Tidak tersedia & 13 & 24,1 \\
\hline & Total & 54 & 100 \\
\hline
\end{tabular}

Sumber : Data hasil olahan,2010

Tabel 3 diatas memperlihatkan ada 7 responden menyatakan sarana perumahan sangat tersedia dan tersedia dengan tingkat persentase $13 \%$ adalah yang terendah, dan terdapat 13 responden dengan pernyataan sarana perumahan tidak tersedia dengan tingkat persentase $24,1 \%$ adalah yang tertinggi. Jelasnya dapat dilihat pada gambar 10 sebagai berikut:

Untuk variabel bebas sarana pada grafik normal P-P plot sarana (X2) yang berpengaruh terlihat pada nilai harapan dari penggunaan lahan menurut tingkat probabilitas yang berpengaruh meningkat di atas 0,6 dan di bawah 0,8 yang terendah, sedang nilai tertinggi berada diatas 0,8 dan dibawah 1,0 mirip dengan grafik nilai lahan dan prasarana ini di sebabkan jumlah responden ketiganya beda-beda tipis.

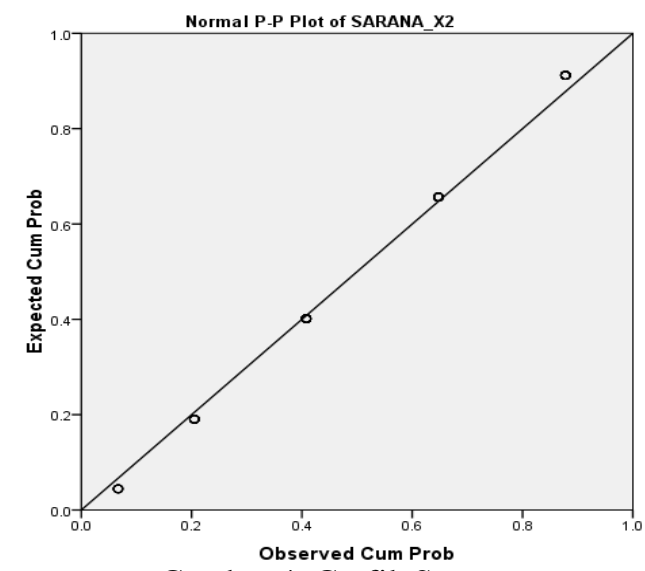

Gambar 4. Grafik Sarana

Gambar grafik garis untuk sarana menunjukan bahwa ketersediaan sarana pada perumahan di kecamatan Panakukang, Tamalanrea dan Biringkanaya agak tersedia maka perlu lebih ditingkatkan lagi, sehingga memberikan pengaruh terhadap nilai lahan. Sarana yang dimaksud yaitu terdiri dari sarana pendidikan, kesehatan, peribadatan, olahraga/rekreasi, dan perbelanjaan.

Suatu perumahan akan ideal dan sesuai dengan ketentuan perumahan yang layak apabila sarana pendukungnya terpenuhi. Karena suatu pengembang perumahan senantiasa mengalokasikan sarana untuk perumahan guna mewujudkan perumahan yang ideal. Ini sesuai dengan yang dikemukakan oleh Muhtar (2000) dalam tinjauan pustaka yang mengatakan bahwa dalam mendapatkan suatu perumahan yang layak huni dan layak tinggal adalah pemukiman yang menyediakan prasarana dan sarana yang terpenuhi untuk keluarga dan anggota keluarga.

\section{d. Interpretasi}

Setelah data-data yang ada terkumpul, maka selanjutnya dilakukan pengolahan data. Data-data tersebut diolah melalui persamaan regresi linear berganda dengan menggunakan bantuan program SPSS, maka didapatkan hasil cetakan yang diformulasikan dalam bentuk persamaan sebagai berikut:

$$
\begin{aligned}
Y & =a+b 1 X 1+b 2 X 2 \\
& =0,563+0,583 X 1+0,358 \times 2
\end{aligned}
$$

Ini menunjukan bahwa: 
1. $\mathrm{a}=0,563$ artinya nilai konstan untuk variabel terikat

2. $\mathrm{b} 1=0,583$ artinya peningkatan prasarana $1 \%$ akan memberikan pengaruh sebesar 0.583 terhadap nilai lahan.

3. $\mathrm{b} 2=0,358$ artinya peningkatan sarana $1 \%$ akan memberikan pengaruh sebesar 0,358 terhadap nilai lahan.

Hasil perhitungan regresi linear berganda dapat dilihat pada tabel 4 .

Tabel 4. Hasil Hitungan Regresi linear berganda

\begin{tabular}{|c|c|c|c|c|c|}
\hline $\begin{array}{c}\text { Varia- } \\
\text { bel }\end{array}$ & $\begin{array}{c}\text { Koef } \\
\text { Reg- } \\
\text { resi }\end{array}$ & $\begin{array}{c}\mathbf{t} \\
\text { Hi-tung }\end{array}$ & Prob. & $\begin{array}{c}\text { Parsial } \\
\left(\mathbf{r}^{2}\right)\end{array}$ & Ket \\
\hline $\begin{array}{c}\text { Pra- } \\
\text { sarana } \\
(\mathrm{X} 1)\end{array}$ & 0,583 & 6,114 & 0,00 & 0,650 & $\begin{array}{c}\text { Sing } \\
\text { nifik } \\
\text { an }\end{array}$ \\
\hline $\begin{array}{c}\text { Sarana } \\
(\mathrm{X} 2)\end{array}$ & 0,358 & 3,751 & 0,00 & 0,465 & $\begin{array}{c}\text { Sign } \\
\text { if ika } \\
\mathrm{n}\end{array}$ \\
\hline $\begin{array}{c}\text { Konstante }=0,563 \\
\mathrm{R}=0,867 \\
\mathrm{R}^{2}=0,752 \\
\text { Adjusted R. Squarted }=0,742\end{array}$ \\
F hitung = 77,407 Signifikan $=0,00$ \\
\end{tabular}

Sumber : Data hasil olahan, 2010

Memperhatikan tabel 4, maka dapat diinterpretasikan sebagai berikut:

1. Koefisien korelasi berganda (R) diperoleh dengan nilai 0,867 atau mendekati angka 1 . Hal ini menunjukan bahwa variabel-variabel bebas yang meliputi prasarana dan sarana mempunyai hubungan yang sangat erat dengan nilai lahan.

2. Koefisien determinasi (R Squared) sebesar 0,752 ini berarti bahwa besarnya sumbangan kedua variabel $\mathrm{X}$ terhadap variabel $\mathrm{Y}$ adalah sebesar $75,2 \%$, dengan kata lain terdapat pengaruh yang kuat dan signifikan antara kedua variabel bebas terhadap nilai lahan.

3. Koefisien determinasi partial $\left(r^{2}\right)$ menunjukan pengaruh sebagai berikut :

a. Pengaruh prasarana (X1) terhadap nilai lahan adalah sebesar 0.650 karena $-1<\mathrm{r}<1$ maka dapat disimpulkan pengaruh variabel prasarana terhadap nilai lahan adalah kuat dan positif dengan tingkat pengaruh $65 \%$.

b. Pengaruh sarana (X2) terhadap nilai lahan adalah sebesar 0.465 , karena $-1<r<1$ maka dapat disimpulkan pengaruh antara variabel sarana terhadap nilai lahan adalah kuat dan positif dengan tingkat pengaruh $46,5 \%$.

Dari kedua variabel independen tersebut diatas, maka variabel $\mathrm{X}$ yang dominan mempengaruhi varaibel $\mathrm{Y}$ berturut-turut adalah prasarana (X1) dan sarana (X2).

4. Uji-t dapat dilihat pada tingkat kepercayaan sebesar $95 \%$ secara statistik menunjukan uji-t dari masing-masing variabel independen yaitu $\operatorname{prasarana}(\mathrm{X} 1)=6,411$ dan $\operatorname{sarana}(\mathrm{X} 2)=3,751$ mempunyai pengaruh signifikan terhadap nilai lahan dengan tingkat signifikansi:

$\mathrm{X} 1-\mathrm{Prob}=0,00<\alpha 0,05$

$\mathrm{X} 2-\mathrm{Prob}=0,00<\alpha 0,05$

Berarti hal ini sesuai dengan hipotesis yang diajukan.

5. Uji-F dapat dilihat pada tingkat kepercayaan sebesar 95\% statistic menunjukan bahwa kedua variabel bebas prasarana dan sarana secara bersama-sama atau simultan sangat signifikan terhadap nilai lahan sebesar 77,407 dengan tingkat signifikansi:

$$
\mathrm{F} \text { - Prob }=0,00<\alpha 0,05
$$

Jadi ditemukan adanya pengaruh prasarana dan sarana terhadap nilai lahan dari perumahanperumahan tersebut.

6. Dari hasil perhitungan regresi liniar berganda dapat pula dilihat mana-mana anggota dari kedua variabel bebas prasarana (X1) dan sarana (X2) yang sangat berpengaruh signifikan terhadap nilai lahan. Jelasnya dapat dilihat melalui:

a. Variabel Prasarana (X1)

Tabel 5. Hasil perhitungan regresi linear berganda variabel Prasarana.

\begin{tabular}{|c|c|c|c|c|c|}
\hline $\begin{array}{l}\text { Varia- } \\
\text { bel } \\
\text { Pra- } \\
\text { sarana } \\
\text { (X1) }\end{array}$ & $\begin{array}{c}\text { Koe- } \\
\text { fisien } \\
\text { Reg- } \\
\text { resi }\end{array}$ & $\begin{array}{c}\mathrm{t} \\
\mathrm{Hi}- \\
\text { tung }\end{array}$ & $\begin{array}{c}\text { Pro } \\
\text { babi } \\
\text { lity }\end{array}$ & $\begin{array}{c}\text { Par- } \\
\text { sial } \\
\left(\mathbf{r}^{2}\right)\end{array}$ & Ket \\
\hline $\begin{array}{l}\text { Jalan } \\
\text { (X1.1) }\end{array}$ & 0,796 & 9,230 & 0,00 & 0,800 & $\begin{array}{c}\text { Sign } \\
\text { ifika } \\
n\end{array}$ \\
\hline $\begin{array}{c}\text { Drai- } \\
\text { nase } \\
(\mathrm{X} 1.2)\end{array}$ & 0,351 & 4,300 & 0.00 & 0,527 & $\begin{array}{c}\text { Sign } \\
\text { ifika } \\
n\end{array}$ \\
\hline $\begin{array}{c}\text { Air } \\
\text { Bersih } \\
\text { (X1.3) }\end{array}$ & 0,711 & 8,644 & 0,00 & 0,780 & $\begin{array}{c}\text { Sign } \\
\text { ifika } \\
n\end{array}$ \\
\hline $\begin{array}{l}\text { Listrik } \\
\text { (X1.4) }\end{array}$ & 0,554 & 7,117 & 0,00 & 0,717 & $\begin{array}{c}\text { Sign } \\
\text { ifika } \\
n\end{array}$ \\
\hline $\begin{array}{c}\text { Tele- } \\
\text { pon } \\
(\mathrm{X} 1.5)\end{array}$ & 0,498 & 6,297 & 0,00 & 0,673 & $\begin{array}{c}\text { Sign } \\
\text { ifika } \\
n \\
\end{array}$ \\
\hline \multicolumn{6}{|c|}{$\begin{array}{l}\text { Konstanta }=3,399 \\
\mathrm{R}=0,865 \\
\mathrm{R}^{2}=0,748 \\
\text { Adjustic } \mathrm{R} \text { Square }=0,722 \\
\mathrm{~F} \text { hitung }=28,568\end{array}$} \\
\hline
\end{tabular}

Sumber : data hasil olahan, 2010

Setelah data-data yang ada terkumpul, maka selanjutnya dilakukan pengolahan data, data-data tersebut diolah melalui persamaan regresi linear berganda dengan menggunakan bantuan SPSS, maka didapatkan hasil cetakan yang diformulasikan dalam bentuk persamaan sebagai berikut ini: 
$\mathrm{Y}=\mathrm{a}+\mathrm{b} 1 \mathrm{X} 1.1+\mathrm{b} 2 \mathrm{X} 1.2+\ldots \ldots \ldots \ldots . . \mathrm{b} 2 \mathrm{X} 1.5$

$\mathrm{Y}=3,399+0,796 \mathrm{X} 1.1+0,351 \mathrm{X} 1.2+0,711$ $\mathrm{X} 1.3+0,554 \mathrm{X} 1.4+0,498 \mathrm{X} 1.5$

Ini menunjukan bahwa:

$\mathrm{a}=3,399$ artinya nilai konstan untuk variabel terikat

$\mathrm{b} 1=0,796$ artinya peningkatan prasarana jalan $1 \%$ akan memberikan pengaruh sebesar 0,796 terhadap nilai lahan

b2 = 0,351 artinya peningkatan prasarana drainase $1 \%$ akan memberikan pengaruh sebesar 0,351 terhadap nilai lahan

b3 $=0,711$ artinya peningkatan prasarana air bersih $1 \%$ akan memberikan pengaruh sebesar 0,711 terhadap nilai lahan

b4 $=0,554$ artinya peningkatan prasarana listrik $1 \%$ akan memberikan pengaruh sebesar 0,554 terhadap nilai lahan

b5 $=0,498$ artinya peningkatan prasarana telepon $1 \%$ akan memberikan pengaruh sebesar 0,499 terhadap nilai lahan.

Dengan memperhatikan hasil hitungan regresi linear berganda yang terdapat pada lampiran, maka hasil analisis tersebut diinterpretasikan sebagai berikut:

1. Koefisien korelasi berganda diperoleh dengan nilai 0,865 atau mendekati angka 1 . Hal ini menunjukan bahwa variabel prasarana sangat erat hubungannya dengan variabel terikat nilai lahan.

2. Koefisien determinasi (R Square) sebesar 0,748 ini berarti bahwa besarnya sumbangan kelima anggota variabel prasarana terhadap variabel nilai lahan adalah sebeasr $74,8 \%$, dengan kata lain terdapat pengaruh yang kuat dan signifikan anggota variabel bebas prasarana terhadap nilai lahan.

3. Koefisien determinasi parsial $\left(\mathrm{r}^{2}\right)$ menunjukan pengaruh sebagai berikut :

a. Pengaruh prasarana jalan (X1.1) terhadap nilai lahan (Y) adalah sebesar 0,800 , karena $-1<\mathrm{r}<1$ maka dapat disimpulkan pengaruh variabel prasarana jalan terhadap nilai lahan adalah kuat dan positif dengan tingkat pengaruh $80 \%$.

b. Pengaruh prasarana drainase (X1.2) terhadap nilai lahan adalah sebesar 0,527, karena $-1<\mathrm{r}<1$ maka dapat disimpulkan pengaruh variabel prasarana drainase terhadap nilai lahan adalah cukup kuat dan positif dengan tingkat pengaruh $52,7 \%$.

c. Pengaruh prasarana air bersih (X1.3) terhadap nilai lahan adalah sebesar 0,780, karena - $1<\mathrm{r}<1$ maka dapat disimpulkan pengaruh variabel prasarana air bersih terhadap nilai lahan adalah kuat dan positif dengan tingkat pengaruh $78 \%$.

d. Pengaruh prasarana listrik (1.4) terhadap nilai lahan adalah sebesar 0,717 , karena $1<\mathrm{r}<1$ maka dapat disimpulkan pengaruh variabel prasarana listrik terhadap nilai lahan adalah kuat dan positif dengan tingkat pengaruh sebesar $71,7 \%$.

e. Pengaruh prasarana telepon (X1.5) terhadap nilai lahan adalah sebesar 0,673, maka dapat disimpulkan pengaruh variabel prasaran listrik terhadap nilai lahan adalah kuat dan positif dengan tingkat pengaruh sebesar $67,3 \%$.

Dari kelima variabel bebas prasarana tersebut diatas, maka variabel prasarana jalan (X1.1) yang paling dominan berpengaruh terhadap nilai lahan.

b. Variabel sarana (X2)

Tabel 6. Hasil perhitungan regresi linear berganda variabel sarana

\begin{tabular}{|c|c|c|c|c|c|}
\hline $\begin{array}{c}\text { Varia- } \\
\text { bel } \\
\text { sarana } \\
\text { (X2) }\end{array}$ & $\begin{array}{l}\text { Koefi } \\
\text { sien } \\
\text { regre } \\
\text { si }\end{array}$ & $\begin{array}{c}\text { t } \\
\text { regr } \\
\text { esi }\end{array}$ & $\begin{array}{c}\text { Proba } \\
\text { biliti }\end{array}$ & $\begin{array}{l}\text { Par } \\
\text { sial } \\
\left(\mathbf{r}^{2}\right)\end{array}$ & Ket \\
\hline $\begin{array}{c}\text { Pendidi } \\
\text { kan } \\
(\mathrm{X} 2.1)\end{array}$ & 0,719 & $\begin{array}{c}7,56 \\
0\end{array}$ & 0,000 & $\begin{array}{c}0,73 \\
7\end{array}$ & $\begin{array}{c}\text { Signifi } \\
\text { kan }\end{array}$ \\
\hline $\begin{array}{c}\text { Kesehat } \\
\text { an } \\
(\mathrm{X} 2.2)\end{array}$ & 0,628 & $\begin{array}{c}6,62 \\
5\end{array}$ & 0,000 & $\begin{array}{c}0,69 \\
1\end{array}$ & $\begin{array}{c}\text { Signifi } \\
\text { kan }\end{array}$ \\
\hline $\begin{array}{c}\text { Peribad } \\
\text { atan } \\
(\mathrm{X} 2.3)\end{array}$ & 0,496 & $\begin{array}{c}5,37 \\
3\end{array}$ & 0,000 & $\begin{array}{c}0,61 \\
3\end{array}$ & $\begin{array}{c}\text { Signifi } \\
\text { kan }\end{array}$ \\
\hline $\begin{array}{c}\text { Olahrag } \\
\text { a } \\
(\mathrm{X} 2.4)\end{array}$ & 0,587 & $\begin{array}{c}6,55 \\
5\end{array}$ & 0,000 & $\begin{array}{c}0,68 \\
7\end{array}$ & $\begin{array}{c}\text { Signifi } \\
\text { kan }\end{array}$ \\
\hline $\begin{array}{c}\text { Perbela } \\
\text { njaan } \\
(\mathrm{X} 2.5)\end{array}$ & 0,682 & $\begin{array}{c}7,24 \\
4\end{array}$ & 0,000 & $\begin{array}{c}0,72 \\
3\end{array}$ & $\begin{array}{c}\text { Signifi } \\
\text { kan }\end{array}$ \\
\hline
\end{tabular}

Konstata $=3,215$

$\mathrm{R}=0,824$

$\mathrm{R}^{2}=0,679$

Adjusted R Square $=0,645$

F hitung $=20,266 \quad$ Signifikan $=0,00$

Sumber : Data hasil olahan, 2010

Setelah data-data yang ada terkumpul, maka selanjutnya dilakukan pengolahan data, data-data tersebut diolah melalui persamaan regresi linear berganda dengan menggunakan bantuan SPSS, maka didapatkan hasil cetakan yang diformulasikan dalam bentuk persamaan sebagai berikut:

$\mathrm{Y}=\mathrm{a}+\mathrm{b} 1 \mathrm{X} 1.1+\mathrm{b} 2 \mathrm{X} 1.2+\ldots \ldots \ldots \ldots . . \mathrm{b} 5 \mathrm{X} 1.5$

$\mathrm{Y}=3,215+0,719 \mathrm{X} 2.1+0,628 \mathrm{X} 2.2+0,496$ $\mathrm{X} 2.3+0,587 \mathrm{X} 2.4+0,682 \mathrm{X} 2.5$

Ini menunjukan bahwa:

$\mathrm{a}=3,215$ artinya nilai konstan untuk variabel terikat

$\mathrm{b} 1=0,719$ artinya peningkatan prasarana jalan $1 \%$ akan memberikan pengaruh sebesar 0,719 terhadap nilai lahan 
$\mathrm{b} 2=0,628$ artinya peningkatan prasarana drainase $1 \%$ akan memberikan pengaruh sebesar 0,628 terhadap nilai lahan

b3 $=0,496$ artinya peningkatan prasarana air bersih $1 \%$ akan memberikan pengaruh sebesar 0,496 terhadap nilai lahan

$\mathrm{b} 4=0,587$ artinya peningkatan prasarana listrik $1 \%$ akan memberikan pengaruh sebesar 0,587 terhadap nilai lahan

$\mathrm{b} 5=0,682$ artinya peningkatan prasarana telepon $1 \%$ akan memberikan pengaruh sebesar 0,682 terhadap nilai lahan

Dengan memperhatikan hasil hitungan regresi linear berganda yang terdapat pada lampiran, maka hasil analisis tersebut di interpretasikan :

1. Koefisien korelasi berganda (R) diperoleh dengan nilai 0,824 atau mendekati angka 1 .

Hal ini menunjukan bahwa variabel sarana sangat erat hubungannya dengan variabeterikat nilai lahan (X2).

2. Koefisien determinasi ( $\mathrm{R}$ Square) sebesar 0,679 ini berarti bahwa besarnya sumbangan kelima anggota variabel sarana terhadap variabel nilai lahan adalah sebesar $67,9 \%$ dengan kata lain terdapat pengaruh yang kuat dan signifikan antara kelima anggota variabel sarana terhadap nilai lahan.

3. Koefisien determinasi parsial menunjukan pengaruh sebagai berikut :

a. Pengaruh sarana pendidikan (X2.1) terhadap nilai lahan (Y) adalah sebesar 0,732, karena $-1<\mathrm{r}<1$ maka dapat disimpulkan pengaruh variabel sarana pendidikan terhadap nilai lahan adalah cukup kuat dan positif dengan tingkat pengaruh sebesar $73,2 \%$.

b. Pengaruh sarana kesehatan (X2.2) terhadap nilai lahan $(\mathrm{Y})$ adalah sebesar 0,691 , karena $-1<\mathrm{r}<1$ maka dapat dikatakan disimpulkan pengaruh variabel kesehatan terhadap nilai lahan cukup kuat dan positif dengan tingkat pengaruh sebesar $69,1 \%$.

c. Pengaruh sarana peribadatan (X2.3) terhadap nilai lahan (Y) adalah sebesar 0,613 , karena $-1<\mathrm{r}<1$ maka dapat disimpulkan pengaruh variabel sarana peribadatan terhadap nilai lahan kuat dan positif dengan tingkat pengaruh $61,3 \%$.

d. Pengaruh sarana olahraga (X2.4) terhadap nilai lahan (Y) adalah sebesar 0,687, karena $-1<\mathrm{r}<1$ maka dapat disimpulkan pengaruh variabel sarana olahraga terhadap nilai lahan kuat dan positif dengan tingkat pengaruh $68,7 \%$.

e. Pengaruh sarana perbelanjaan (X2.5) terhadap nilai lahan $(\mathrm{Y})$ adalah sebesar 0,723 , karena $-1<\mathrm{r}<1$ maka dapat disimpulkan pengaruh variabel perbelanjaan terhadap nilai lahan cukup kuat dan positif dengan tingkat pengaruh sebesar $72,3 \%$.

Dari kelima anggota variabel sarana tersebut diatas, maka variabel sarana pendidikan yang paling dominan berpengaruh terhadap variabel nilai lahan.

\subsection{Pembahasan Hasil}

a. Hasil uji linearitas regresi:

$$
\mathrm{Y}=\mathrm{a}+\mathrm{b} 1 \mathrm{X} 1+\mathrm{b} 2 \mathrm{X} 2
$$

Akan diperoleh dua kesimpulan nilai rata-rata kenaikan lahan:

1. Untuk prasarana

$$
\begin{aligned}
\mathrm{Y} & =\mathrm{a}+\mathrm{b} 2 \mathrm{X} 1 \\
\mathrm{Y} & =0,563+0,583 \mathrm{X} 1 \\
& =0,563+0,583(5) \\
& =0,563+2,915 \\
& =3,478
\end{aligned}
$$

Nilai rata-rata kenaikan tanah sebesar 3,478. Dari persamaan regresi tersebut menunjukkan bahwa, bila nilai kualitas layanan prasarana bertambah 1 maka nilai lahan akan bertambah 0,583 atau setiap nilai kualitas layanan bertambah 10 maka nilai rata-rata kenaikan lahan akan bertambah 5,83.

2. Untuk sarana

$$
\begin{aligned}
\mathrm{Y} & =\mathrm{a}+\mathrm{b} 2 \mathrm{X} 2 \\
\mathrm{Y} & =0,563+0,358(5) \\
& =0,563+1,790 \\
\mathrm{Y} & =2,353
\end{aligned}
$$

Nilai rata-rata kenaikan tanah sebesar 2,353. Dari persamaan regresi diatas menunjukkan bahwa jika nilai kualitas layanan sarana bertambah 1, maka nilai lahan akan bertambah 0,358 atau setiap nilai kualitas layanan bertambah 10 maka nilai rata-rata kenaikan lahan akan bertambah 3,58.

b. Dari koefisien korelasi berganda (R) diperoleh nilai 0,867 lebih besar dari nilai korelasi parsial $\mathrm{X} 1=0,650$ dan X2 = 0,465

Dari hasil uji $\mathrm{F}$ dapat dilihat pada tingkat kepercayaan sebesar 95\% statestik menunjukan bahwa variabel bebas (X1 dan X2) secara simultan berpebgaruh signifikan terhadap variabel nilai lahan (Y) sebesar 77,407 dengan tingkat signifikansi:

$$
\mathrm{F}-\mathrm{Prob}=0,00<\alpha 0,05
$$

Hal ini menunjukan bahwa variabel-variabel bebas (X1 dan X2) mempunyai hubungan yang sangat erat dengan nilai lahan.

c. Untuk melihat apakah koefisien parsial yang ditemukan signifikan atau tidak maka dilakukan uji-t.

Hasil uji-t dapat dilihat dari tingkat kepercayaan sebesar $95 \%$ secara statistik menunjukan bahwa nilai variabel bebas prasarana $(X 1=6,411)$ dan variabel sarana $(\mathrm{X} 2=3,765)$ mempunyai pengaruh yang signifikan terhadap nilai lahan dengan tingkat signifikansi: 


$$
\begin{aligned}
& \mathrm{X} 1-\text { prob }=0,00<\alpha 0,05 \\
& \mathrm{X} 2-\text { prob }=0,00<\alpha 0,05
\end{aligned}
$$

Berarti hal ini sesuai dengan hipotesis yang diajukan, bahwa koefisien korelasi adalah signifikan.

d. Dari nilai koefisien determinasi $\left(\mathrm{r}^{2}\right)$ menunjukan:

1. Pengaruh prasarana $(\mathrm{X} 1=0,650)$ dan sarana $(\mathrm{X} 2=0,465)$ terhadap nilai lahan adalah kuat dan positif karena $-1<\mathrm{r}<1$ dengan tingkat pengaruh masing-masing variabel $65 \%$ dan 46,5\%. Dari kedua variabel bebas (X1 dan $\mathrm{X} 2$ ), variabel $\mathrm{X} 1$ yang paling dominan mempengaruhi variabel terikat nilai lahan (Y).

2. Pengaruh prasarana jalan $(\mathrm{X} 1.1=0,800)$, prasarana drainase $(\mathrm{X} 1.2=0,527)$, prasarana air bersih $(\mathrm{X} 1.3=0,780)$, prasarana listrik $(\mathrm{X} 1.4=0,717)$, dan prasarana telepon $(\mathrm{X} 1.5$ $=0,673)$ terhadap nilai lahan $(\mathrm{Y})$ adalah kuat dan positif karena $-1<\mathrm{r}<1$ dengan tingkat pengaruh masing-masing: $\mathrm{X} 1.1=80 \%, \mathrm{X} 1.2$ $=52,7 \%, \mathrm{X} 1.3=78 \%, \mathrm{X} 1.4=71,7 \%$, dan $\mathrm{X} 1.5=67,3 \%$. Dari kelima variabel bebas prasarana yang paling dominan berpengaruh adalah jaringan jalan (X1.1), dimana jalan merupakan factor utama yang dapat menaikkan nilai lahan suatu tempat, menginagat jalan adalah akses yang menghubungkan tempat yang satu dengan tempat yang lain. Sehingga dengan demikian keberadaan jaringan jalan akan mendorong perkembangan prasarana dasar lingkungn yang lain.

3. Pengaruh variabel sarana pendidikan $(\mathrm{X} 2.1=$ $0,737)$, sarana kesehatan $(X 2.2=0,691)$, sarana peribadatan $(\mathrm{X} 2.3=0,613)$, sarana olahraga $\quad(X 2.4=0,687), \quad$ dan sarana perbelanjaan $(\mathrm{X} 2.5=0,723)$ terhadap nilai lahan (Y) adalah kuat dan positif karena $-1<$ $\mathrm{r}<1$ dengan tingkat pengaruh masingmasing: $\mathrm{X} 2.1=73,7 \%, \mathrm{X} 2.2=69,1 \%, \mathrm{X} 2.3$ $=61,3 \%, \mathrm{X} 2.4=68,7 \%$, dan X2.5 $=72,3 \%$. Dari kelima variabel sarana yang paling dominan adalah sarana pendidikan $(73,7 \%)$ mengingat pendidikan tingkat TK dan SD masih memerlukan pengawasan dari orang tua sehingga perlu letaknya dekat dengan tempat tinggal, dan peringkat kedua di duduki oleh sarana perbelanjaan yang merupakan sarana pelayanan kebutuhan hidup seharihari. Sehingga dengan keberadaan kedua sarana tersebut sangat mendukung kebutuhan hidup sehari-hari masyarakat penghuni perumahan.

\section{PENUTUP}

\subsection{Kesimpulan}

1. Hasil penelitian menunjukan bahwa nilai $\mathrm{r}^{2}=$ 0,650 prasarana dan $r^{2}=0,465$ sarana memberikan kontribusi pengaruh sebesar $65 \%$ dan $46,5 \%$ terhadap nilai lahan perumahan. Dengan tersedianya prasarana dan sarana perumahan. maka nilai lahan yang dimiliki oleh suatu perumahan tinggi.

2. Prasarana $(\mathrm{X} 1)=6,114$ adalah dominan memberikan pengaruh signifikan kuat terhadap nilai lahan suatu perumahan, tanpa mengabaikan variabel bebas sarana $(\mathrm{X} 2)=3,751$ yang juga memberikan pengaruh signifikan terhadap nilai lahan pada perumahan.

3. Anggota dari variabel bebas prasarana (X1) yang paling dominan berpengaruh terhadap nilai lahan adalah prasarana jalan (X1.1).

4. Anggota dari variabel bebas sarana (X2) yang paling dominan berpengaruh terhadap nilai lahan adalah sarana pendidikan (X2.1).

\subsection{Saran}

1. Disarankan hasil penelitian ini dapat menjadi masukan bagi pengembang perumahan dalam menentukan kebijakan-kebijakan mengenai ketersediaan prasarana dan sarana, sehingga memberikan pengaruh terhadap nilai lahan perumahan.

2. Prasarana perumahan di ketiga kecamatan (Panakkukang, Talanrea, Biringkanayya) berpengaruh dominan, karena ketersediaan jalan, drainase, air bersih, listrik dan telepon merupakan suatu hal yang sangat diperlikan untuk kelayakan suatu perumahan.

\section{DAFTAR PUSTAKA}

- Dwi Priyatnbo. Mandiri Belajar SPSS. Penerbit Mediakom, Yogyakarta. 2008.

- Departemen Pekerjaan Umum. Prasarana dan Sarana Perumahan Jakarta. 2001.

- Djoyodipuro, Adyaksa. Karakteristik Pemukiman dalam Tata Guna Lahan. Penerbit Kanisius, Yogjakarta. 1998.

- Ilham Andi. Evaluasi Ketersediaan dan Pelayanan Prasarana Lingkungan di Kawasan Perumahan Bumi Antang Permai Kota Makassar. 2006.

- Lukman. Pengantar dalam Pengklasifikasian Lahan. Penerbit Yayasan Padamu Negeri, Jakarta. 1998.

- Menteri Pekerjaan Umum No. 20/KPTS/1986. Pedoman Teknis Pembangunan Perumahan Sederhana.

- Sadikin. Menentukan Prasarana, Sarana dan Nilai Lahan Penerbit Elex Media Komputindo, Jakarta. 1998.

- Safaat, Alisyahbana. Pembangunan Perumahan dan Pemukiman Kota. Penerbit Putaka Pelajar, Yogyakarta. 2001.

- Sanusi Alam. Perencanaan Kawasan Perumahan Kota. Penerbit Kanisius, Yogyakarta. 2001.

- Siswono. Perumahan dan Pemukiman. Penerbit Mandar maju, Jakarta. 1998. 
- Sugiono. Statistika untuk Penelitian. Penerbit Alfabeta Bandung. 2007.

- Sutarman. Sarana dan Prasarana Pemukiman Kota Metropolitan. Penerbit Pustaka Jaya, Jakarta. 2000.

- Trihendradi C. Tujuh Langka Mudah Melakukan Analisis Statistik Menggunakan SPSS 17. Penerbit CV. Andi, Yogyakarta. 2009.

- Undang-Undang No. 4 Tahun 1992. Perumahan dan Pemukiman. 